\title{
Comparison of Viral Replication, Antiviral Gene Expression and Antioxidant Enzyme Activity in Gibel Carp (Carassius auratus gibelio) Infected with Cyprinid Herpesvirus 2 at Susceptible and Less-susceptible Temperatures
}

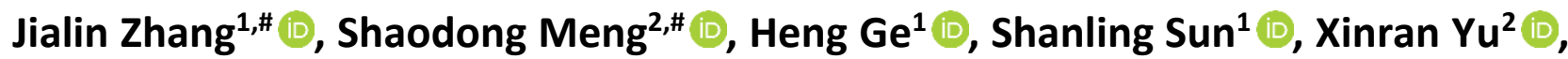 \\ Guo Qiao ${ }^{1}$, Qiang $\mathbf{L i}^{1, *}$ (1)
}

\footnotetext{
${ }^{1}$ Yancheng Institute of Technology, Department of Ocean Technology, College of Marine and Biology Engineering, Yancheng, 224051, China.

2Dalian Ocean University, Key Laboratory of Mariculture \& Stock Enhancement in North China's Sea, Ministry of Agriculture and Rural Affairs, Dalian, 116023, China.

\#These authors share the first authorship.
}

\section{How to cite}

Zhang, J., Meng, S., Ge, H., Sun, S., Yu, X., Qiao, G., Li, Q. (2022). The Comparison of Viral Replication, Antiviral Gene Expression and Antioxidant Enzyme Activity in Gibel Carp (Carassius auratus gibelio) Infected with Cyprinid Herpesvirus 2 at Susceptible and Less-susceptible Temperatures. Turkish Journal of Fisheries and Aquatic Sciences, 22(4), TRJFAS20623. http://doi.org/10.4194/TRJFAS20623

\section{Article History}

Received 13 September 2021

Accepted 29 November 2021

First Online 30 November 2021

\section{Corresponding Author}

Tel.: +8615251132035

E-mail: fish790608@163.com

\section{Keywords}

Cyprinid herpesvirus 2

Carassius auratus gibelio

Temperature

Immune

Antioxidant enzyme

\begin{abstract}
Cyprinid herpesvirus 2 is a DNA virus that is a concern for the aquaculture worldwide. Here, the challenge of CyHV-2 infection was conducted in gibel carp at a host susceptible temperature $\left(25^{\circ} \mathrm{C}\right)$ and a less-susceptible temperature $\left(15^{\circ} \mathrm{C}\right)$. The viral replication and expression of antiviral genes were analyzed by real time PCR, and the activities of antioxidative enzymes in serum were also examined. Results showed that CyHV-2 was in normal proliferative in $25^{\circ} \mathrm{C}$ group, while the growth was inhibited in $15^{\circ} \mathrm{C}$ group. Moreover, IFN $\phi 1$ and $\mathrm{Mx}$ were highly expressed from $12 \mathrm{hpi}$ to $48 \mathrm{hpi}$ in both groups, but the $15{ }^{\circ} \mathrm{C}$ group showed quicker and stronger response. TNF- $\alpha$ and IL-1 $\beta$ showed early upregulation at $12 \mathrm{hpi}$ followed by a sharp decline in both groups. Fatty acid synthase (FAS) and Caspase- 8 showed a higher expression level in $15^{\circ} \mathrm{C}$ group than that in $25^{\circ} \mathrm{C}$ group during $48-96 \mathrm{hpi}$. Furthermore, the activities of antioxidant enzymes (SOD and CAT) in $15^{\circ} \mathrm{C}$ group were higher than those in $25^{\circ} \mathrm{C}$ group at late infection. Thus, water temperature affected the immune response against CyHV-2 infection, which may ultimately lead to host survival in the lesssusceptible temperatures.
\end{abstract}

Introduction

Cyprinid herpesvirus 2 (CyHV-2) is an emerging pathogen that has caused huge economic losses. It is a large DNA virus that belongs to the genus Cyprinivirus within the family Alloherpesviridae (Liu et al., 2018). At first, the disease caused by CyHV-2 infection was reported in the cultured goldfish Carassius auratus in Japan in 1995(Jung \& Miyazaki, 1995). Subsequently, it has spread rapidly to many countries including China ( $\mathrm{Xu}$ et al., 2013), Turkey (Kalayci et al., 2018) and some European countries (Fichi et al., 2013). Owing to its high morbidity and mortality, CyHV-2 has become a major concern to the culture industry of goldfish and gibel carp throughout the world. Unfortunately, there are lack of efficient drugs or measures to control CyHV-2 infection until now.

Fish is typically poikilothermic animal whose life activity extremely affected by water temperature. In recent years, the impact of water temperature on the disease resistance of fish has drawn an increasing interest worldwide, especially focusing on the aquatic virus infection. There exists a close relationship between water temperature and virus infection. For example, 
viral haemorrhagic septicaemia virus (VHSV) infection often occurs at the temperature below $15{ }^{\circ} \mathrm{C}$, causing $50-70 \%$ mortalities in fish but no mortality is observed at temperature above $20^{\circ} \mathrm{C}$ (Kim et al., 2009). Besides, it was reported that warm-water culture conditions could inhibit the replication of WSSV in Litopenaeus vannamei (Piamsomboon et al., 2016). As for CyHV-2, typical symptoms like hyperaemia in the jaws and reddening gill by CyHV-2 infection often occurred at water temperature above $20{ }^{\circ} \mathrm{C}$ (Ito \& Maeno, 2014). Understanding why temperature could affect the disease course is necessary for establishing the epidemic prevention and control measures of CyHV-2 infection.

It is well-known that the immune system of fish plays a key role in defense against various pathogens' invasion. However, the defensive capacity of the host immune system is susceptible to many environment factors including water temperature, and it may increase the risk of disease outbreak when the host immune is weakened or inhibited. Recently, it has been demonstrated that there may exist somewhat relationship between the temperature and the immune system of fish. As reported, the expression levels of several antiviral molecules tend to be temperaturedependent after virus infection (Avunje et al., 2012). Besides, fish survived from virus infection at a lesssusceptible water temperature can acquire an effective prevention against the virus reinfection (Chai et al., 2020).

Nowadays, gibel carp has become one of the most cultured fishes in the region of Yangtze River in China (Ren et al., 2021). They can grow well between $4{ }^{\circ} \mathrm{C} 30$ ${ }^{\circ} \mathrm{C}$ with the optimum growth temperature of $15^{\circ} \mathrm{C} 25$ ${ }^{\circ} \mathrm{C}$ (Li et al., 2016). However, the development of gibel carp culture is challenged by the emergence of gibel carp haematopoietic necrosis caused by CyHV-2 infection (Zhu et al., 2015). The objective of this study was to investigate the difference of viral replication, antiviral gene expression and antioxidant enzyme activity in gibel carp infected with CyHV-2 at susceptible and less-susceptible temperatures. We chose a host susceptible temperature $\left(25^{\circ} \mathrm{C}\right)$ and a less-susceptible temperature $\left(15^{\circ} \mathrm{C}\right)$. Gibel carp were intraperitoneally injected with CyHV-2 and reared at $15{ }^{\circ} \mathrm{C}$ and at $25^{\circ} \mathrm{C}$, respectively. The viral load kinetics and the expression profiles of several antiviral genes in the spleen were examined by real-time PCR in both groups. Moreover, the activities of two antioxidant enzymes (SOD and CAT) in serum were also measured to evaluate the stress response under the two temperatures.

\section{Materials and Methods}

\section{Fish and Virus}

Healthy gibel carp (average body weight of $30 \pm$ $0.5 \mathrm{~g}$ ) were obtained from a local farm in Yancheng city, Jiangsu province, China. The fish were confirmed to be initially free from CyHV-2 by the PCR detection (Wang et al., 2015). Then the fish were kept in fiberglass tanks supplied with aerated water and fed with the commercial diet before the experiment. No fish died or displayed symptoms like anorexia, apathy, or necrotic spots on the jaws during the period.

CyHV-2 strain used here was isolated from a moribund gibel carp in a farm in Yancheng, Jiangsu Province (Zhang et al., 2020). The diseased fish exhibited typical symptoms of CyHV-2 infection, with a cumulative mortality of approximate $85 \%$ within 1 week. The spleen was pooled, homogenized in PBS, and centrifuged. Then the supernatant containing CyHV-2 virions was stored at $-80{ }^{\circ} \mathrm{C}$ until use.

\section{Experimental Infection}

Firstly, a total of 200 gibel carp were randomly divided into two groups (100 fish per group) and maintained at $15 \pm 0.5^{\circ} \mathrm{C}$ and $25 \pm 0.5^{\circ} \mathrm{C}$, respectively. For each temperature group, the fish were randomly distributed into the infection group $(n=50)$ and control group $(n=50)$ after acclimation for 7 days. Fish in the infection group were intraperitoneally injected with 100 $\mu \mathrm{L}$ of virus suspension $\left(5 \times 10^{6}\right.$ copies/fish), while those in the control group were intraperitoneally injected with $100 \mu \mathrm{L}$ of PBS. Afterwards, five fish were randomly chosen per tank at $0,12,24,48,72,96$ and $120 \mathrm{~h}$ postinfection (hpi). Fish were aseptically dissected, and the spleen were sampled for DNA and RNA extraction. Alongside, the blood from each individual fish was sampled and the serum were isolated. All procedures were carried out according to the Chinese legislation for animal experimentation guidelines.

\section{Virus Detection}

Quantitative real-time PCR was performed to determine the virus replication. Firstly, the total DNA was extracted from the spleen samples using Ezup Column Animal Genomic DNA Purification Kit (Sangon Biotech, China) according to the manufacturer's protocols. The concentration of extracted DNA was adjusted to $50 \mathrm{ng} / \mu \mathrm{L}$ and used for the template. Using the specific primers targeting CyHV-2 (Table 1), the reaction was performed on a CFX96 Touch Real-Time PCR Detection System (Bio-Rad, Germany). The reaction mixtures in a final volume of $20 \mu \mathrm{L}$ contained $2 \mu \mathrm{L}$ of diluted DNA, $5 \mu \mathrm{mol}$ of each primer, and $10 \mu \mathrm{L}$ of PrimeScript RT Enzyme Mix (TaKaRa, Japan). The reaction was run in triplicates for each sample. Finally, CyHV-2 DNA loads were determined by extrapolating Ct values from the standard curve and expressed as mean $\log _{10}$ copies/100 ng DNA (Qiao et al., 2018).

\section{Total RNA Extraction and Reverse Transcription}

Total RNA was extracted from the spleen samples using the RNAiso reagent (TaKaRa, Japan) following the manufacturer's instructions. The RNA quality was 
Table 1. Detailed information of the primers used for real time PCR

\begin{tabular}{|c|c|c|}
\hline Primers & Primer sequences $\left(5^{\prime}-3^{\prime}\right)$ & Reference \\
\hline$M x-F$ & ACAAAGCAAGAAACGATTAACCTGG & Mou, C. Y. et al. (2018) \\
\hline$M x-R$ & TCTACAACTGTCTGTTCAGTGCCCTT & \\
\hline IFN $\phi 1-F$ & GCTTCGGGAAATGAGTGGACAAT & Mou, C. Y. et al. (2018) \\
\hline IFN $\phi 1-F$ & TTCACTTTTGTTAGATTCCATTGCG & \\
\hline TNF $\alpha-F$ & САTTCCTACGGATGGCATTTACTT & Grayfer, L. et al. (2009) \\
\hline TNF $\alpha-R$ & CCTCAGGAATGTCAGTCTTGCAT & \\
\hline IL-1ß-F & GCGCTGCTCAACTTCATCTTG & Grayfer, L. et al. (2009) \\
\hline IL-1ß-R & GTGACACATTAAGCGGCTTCAC & \\
\hline Caspase 8-F & CTGTTTTGGGCGTGGATG & Lu, J. et al. (2018) \\
\hline Caspase 8-R & CCTTGGCAGGCTTGAATG & \\
\hline FAS-F & ССАAАAТАACACСАСССАСААСТА & Liu, M. et al. (2018) \\
\hline FAS-R & ATGCCAAAGAGCCTGAAAACC & \\
\hline$\beta$-actin- $F$ & СТССССТСААТСССАAAGCCAA & Liu, M. et al. (2018) \\
\hline$\beta$-actin-R & ACACCATCACCAGAATCCATCA & \\
\hline CyHV2-F & TTAGCGTCAGGTCCATAG & Xu, L. et al. (2014) \\
\hline CyHV2-R & GGCGTGTAGAAATCAAACT & \\
\hline
\end{tabular}

checked by $1 \%$ agarose gel electrophoresis and the concentration was determined using a Nanodrop ND2000 spectrophotometer (Quawell, USA). Then $1 \mu \mathrm{g}$ of total RNA was reversely transcribed into cDNA using PrimeScript RT reagent Kit with gDNA Eraser (TaKaRa, Japan). The resulting cDNA was used to determine the expression profiles of antiviral genes after CyHV-2 infection under different water temperatures.

\section{Expression Profiles of Antiviral Genes}

We further investigate the expression profiles of antiviral genes after CyHV-2 infection at host susceptible and less-susceptible temperatures. Using the resulting cDNA as templates and $\beta$-actin was chosen as a reference gene, the expression levels of $\mathrm{Mx}$, IFN $\phi 1$, TNF$\alpha, \mathrm{IL}-1 \beta$, FAS and Caspase- 8 in spleens were examined with relative real-time PCR. All primers were listed in Table 1. The reaction mix contained $10 \mu \mathrm{L}$ of PrimeScript RT Enzyme Mix, $2 \mu \mathrm{L}$ of diluted cDNA, $0.4 \mu \mathrm{L}$ of each primer $(10 \mathrm{mM})$, and RNase-free water to a volume of $20 \mu \mathrm{L}$. Each reaction was run in triplicates to minimize errors. Finally, the melting curve analysis from $60{ }^{\circ} \mathrm{C}$ to $95{ }^{\circ} \mathrm{C}$ was conducted to confirm the amplified product was single. The relative expression level of each gene was normalized to $\beta$-actin and analyzed by $2^{-\triangle \Delta \mathrm{ct}}$ method.

\section{Determination of Antioxidant Enzymes Activities}

For antioxidant enzymes activities analysis, the activities of superoxide dismutase (SOD) and catalase (CAT) in serum were measured using the corresponding test kits (NanJing JianCheng Bio Inst, China) according to the manufacturer's protocols. The SOD activity was measured spectrophotometrically at $550 \mathrm{~nm}$. One unit of SOD activity was defined as the amount of enzyme that caused a $50 \%$ inhibition of nitro blue tetrazolium. The CAT activity was measured spectrophotometrically at $240 \mathrm{~nm}$. One unit of CAT activity was defined as the activity required to destroy $1 \mu \mathrm{mol} \mathrm{H}_{2} \mathrm{O}_{2}$ at $25^{\circ} \mathrm{C}$ in 0.2 $\mathrm{mol} / \mathrm{L}$ phosphate buffer for $1 \mathrm{~min}$. All enzyme assays were carried out on ice and repeated for 3 times. The changes in absorbance were monitored to determine the enzyme activities using a microplate reader (KHB, China).

\section{Statistical Analysis}

Results were subjected to the statistical analyses using SPSS 21.0 software. The data are presented as mean \pm SE $(n)$, where $n$ is the number of samples. Differences between control and treatment groups were assessed by one-way ANOVA. Statistical significance was accepted at $\mathrm{P}<0.05$ and Tukey's multiple comparison post hoc tests to determine differences.

\section{Results}

\section{CyHV-2 Loads in Spleen Under $15^{\circ} \mathrm{C}$ and $25^{\circ} \mathrm{C}$}

Here, we investigated the dynamic changes of viral load in gibel carp both in the $15{ }^{\circ} \mathrm{C}$ group and the $25^{\circ} \mathrm{C}$ group as an indicator of viral replication. Gibel carp were infected artificially with CyHV-2 and the viral DNA loads in spleens were examined by qPCR. In our previous study, gibel carp were infected with CyHV-2 at $15{ }^{\circ} \mathrm{C}$ and $25{ }^{\circ} \mathrm{C}$, and the survival rate was $5 \%$ and $100 \%$, respectively (Data not shown). That was in accordance with the epidemiological surveys for the disease. As shown in Figure 1, the viral DNA copies in the spleen of gibel carp was detected as early as $12 \mathrm{hpi}$ in both groups. With the extension of the infection time, the virus loads in the $15^{\circ} \mathrm{C}$-group were maintained at $10^{5}$ copies $/ 100$ ng DNA, while that of the $25{ }^{\circ} \mathrm{C}$-group reached above $10^{8.4}$ copies/100 ng DNA, suggesting that the virus growth was inhibited in the $15^{\circ} \mathrm{C}$ group. 


\section{Expression Kinetics of Antiviral Genes Under $15^{\circ} \mathrm{C}$ and} $25^{\circ} \mathrm{C}$

Expression kinetics of diverse classes of antiviral genes in the spleen of virus-infected gibel carp under 15 ${ }^{\circ} \mathrm{C}$ and $25{ }^{\circ} \mathrm{C}$ were investigated (Figure 2). For the interferon-related genes (IFN $\phi 1$ and $M x$ ), the genes were highly expressed from $12 \mathrm{hpi}$ to $48 \mathrm{hpi}$ in both groups with a tendency of increase first and then decline later. Particularly, the $15{ }^{\circ} \mathrm{C}$ group showed rapid and strong expression of interferon-related genes in contrast with the delayed response in the $25{ }^{\circ} \mathrm{C}$ group. For inflammatory cytokines (TNF- $\alpha$ and IL-1 $\beta$ ), the genes in the $15^{\circ} \mathrm{C}$ group were up-regulated from at $12 \mathrm{hpi}$ and $24 \mathrm{hpi}$ and subsequently maintained at a low level by the end of the trial. As for the $25{ }^{\circ} \mathrm{C}$ group, the expression profiles of two genes had a transient upregulation at 12 hpi and decreased drastically later. For apoptosisrelated genes (FAS and Caspase-8), the expression levels were very low at $12 \mathrm{hpi}$ and $24 \mathrm{hpi}$ in both the experimental groups. However, the two genes showed a relatively higher expression level in the $15^{\circ} \mathrm{C}$ group than that in the $25^{\circ} \mathrm{C}$ group during $48-96 \mathrm{hpi}$.

\section{Antioxidant Enzyme Activities Under $15{ }^{\circ} \mathrm{C}$ and $25^{\circ} \mathrm{C}$}

The activity of two antioxidant enzymes (SOD and CAT) were examined to evaluate the stress response at the two temperatures. As shown in Figure 3, a significant reduction in antioxidant enzyme activities was found during the CyHV-2 infection in both groups. At the late stage of CyHV-2 infection, it was observed that the levels of the antioxidant enzymes in the $15{ }^{\circ} \mathrm{C}$ group were relatively higher than those in the $25^{\circ} \mathrm{C}$ group.

\section{Discussion}

Recently, the development of gibel carp culture is challenged by the emergence of gibel carp hematopoietic necrosis caused by CyHV-2 infection. Previous study showed that the mortality caused by some aquatic viruses was closely related to water temperature, which was described as the abiotic master factor for fishes. Thus, it is necessary to explore the relationship between the CyHV-2 infection in the host and water temperature. As for CyHV-2, high mortality caused by infection is often recorded at temperatures above $20^{\circ} \mathrm{C}$ by the epidemiological survey but hardly happens at temperatures below $15^{\circ} \mathrm{C}$ (Ouyang et al., 2020). For this reason, we conducted the CyHV-2 infection artificially under $15^{\circ} \mathrm{C}$ and $25^{\circ} \mathrm{C}$, to clarify the difference of CyHV-2 infection in gibel carp under susceptible and less-susceptible temperatures. In the present study, we investigated the viral DNA replication, the antiviral genes expression and antioxidant enzyme response in gibel carp after CyHV-2 infection at the two temperatures.

Previous studies had showed that there were close relationships between temperature and virus replication (Chung et al., 2015). As for CyHV-2, Ito et al. found that cumulative mortalities of Ryukin goldfish infected with CyHV-2 at $15^{\circ} \mathrm{C}$ and $25^{\circ} \mathrm{C}$ were $10 \%$ and $90 \%$ (Ito et al., 2013). However, the virus could grow well at both $15{ }^{\circ} \mathrm{C}$ and $25{ }^{\circ} \mathrm{C}$ in RyuF-2 cells, indicating that the replication of $\mathrm{CyHV}-2$ was not inhibited at $15^{\circ} \mathrm{C}$ in vitro (Ito et al., 2013). In this study, we found that there was obvious difference in viral loads of virus-infected gibel carp between $15^{\circ} \mathrm{C}$ and $25^{\circ} \mathrm{C}$. The viral DNA copies in the $25^{\circ} \mathrm{C}$ group rapidly increased and reached their

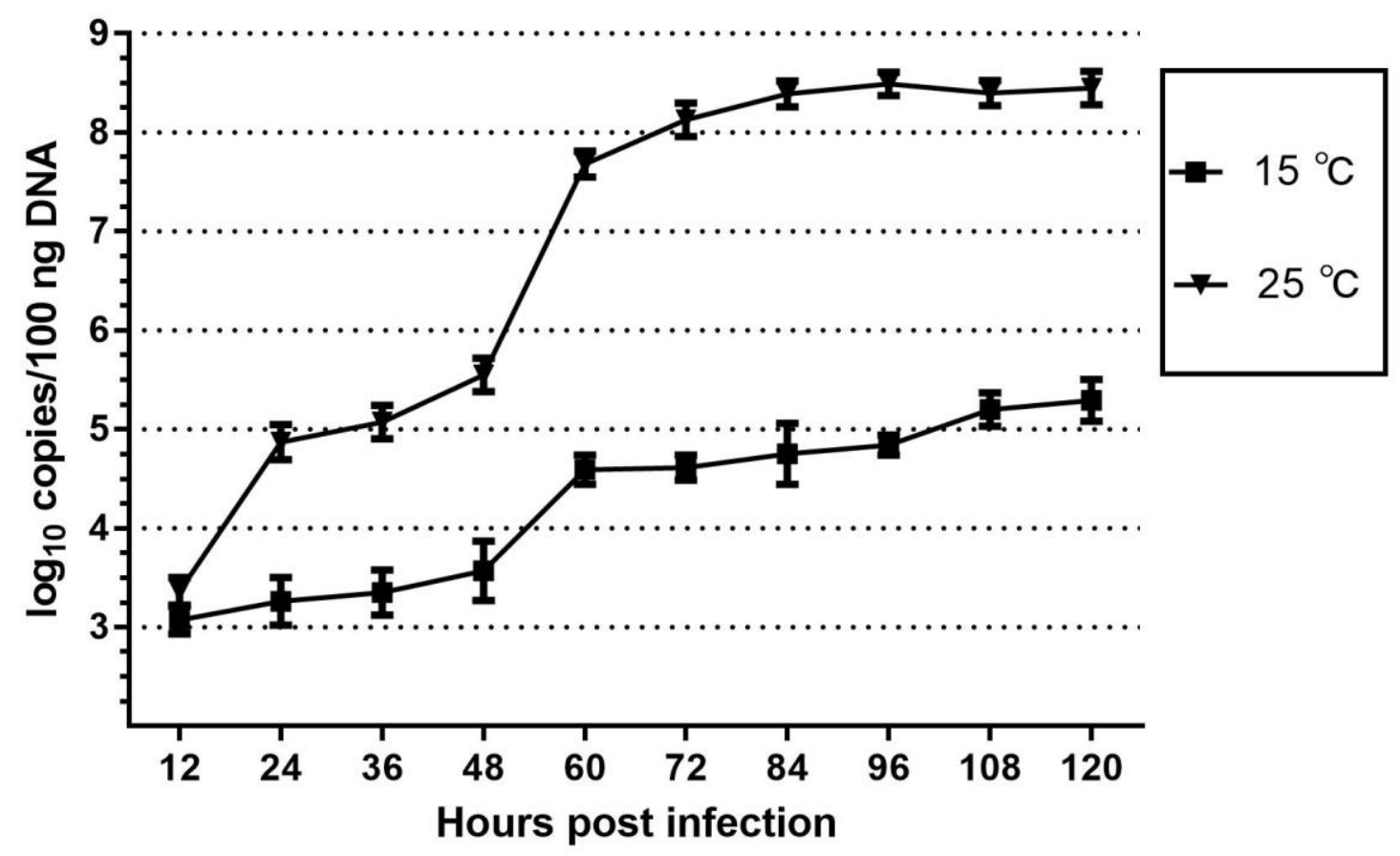

Figure 1. Viral DNA copies of CyHV-2 in the spleen of gibel carp maintained at $15^{\circ} \mathrm{C}$ and $25^{\circ} \mathrm{C}$. 
IFN $\varphi 1$

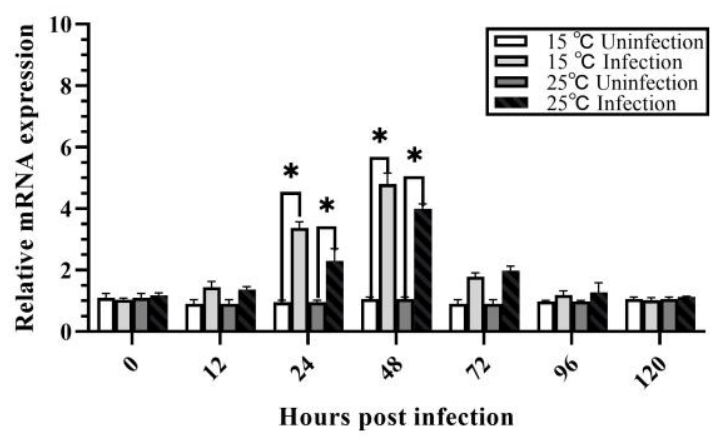

TNFa

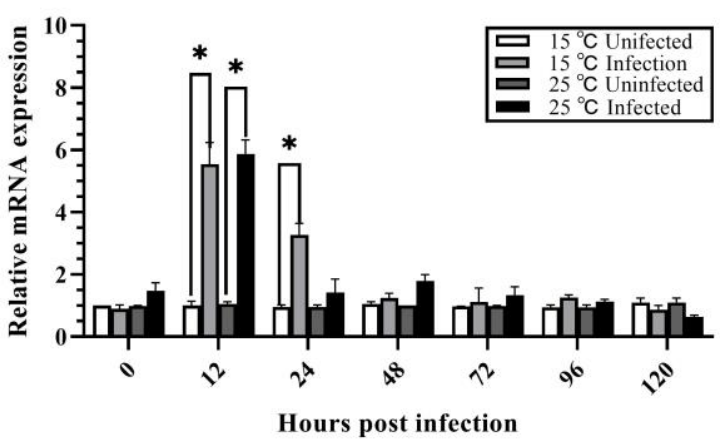

FAS

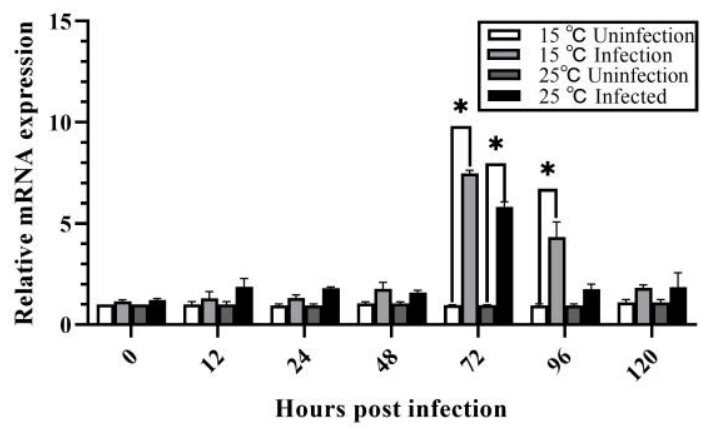

Mx

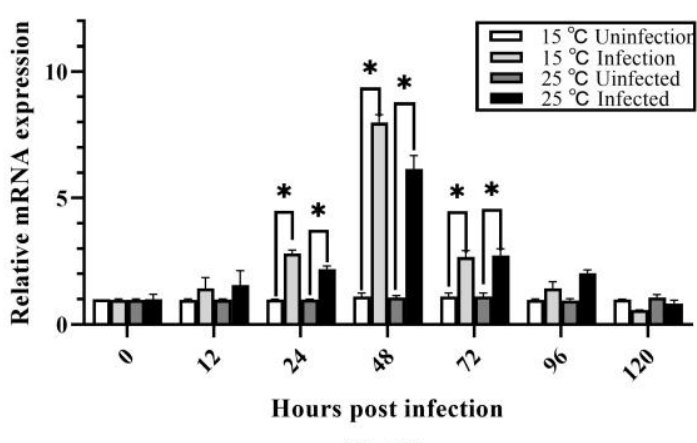

IL-1及

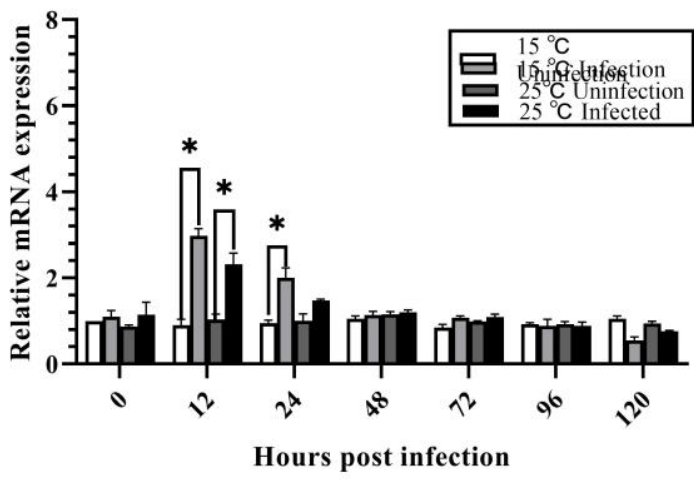

Caspase 8

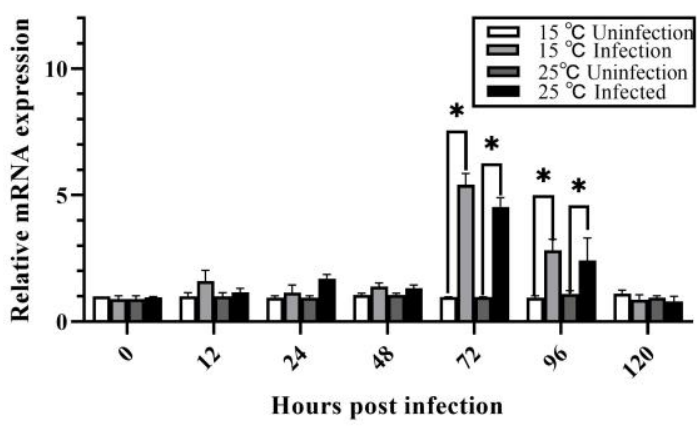

Figure 2. Expressions profiles of antiviral genes in spleen of gibel carp maintained at $15{ }^{\circ} \mathrm{C}$ and $25{ }^{\circ} \mathrm{C}$. Expression levels were normalized against the $\beta$-actin. The relative expression was plotted with standard error against the time after infection.

peaks by $72 \mathrm{hpi}$, while those in the $15^{\circ} \mathrm{C}$ group increased slowly to a stable value by the end of the trial (shown in Figure 1). In gibel carp, the viral DNA replication was inhibited when infected with CyHV-2 at $15{ }^{\circ} \mathrm{C}$, which may lead to host survival.

The influence of water temperature on virus infection involves a set of complex interactions between the virus and the host immune system (Kayansamruaj et al., 2014). In fish, several studies have demonstrated that there were temperature-dependent immune responses during virus infection (Zhang et al., 2017). Among them, interferon-mediated immune responses are key to establish an antiviral defense and inhibit viral replication (Mou et al., 2018). In this study, two interferon-related genes (IFN $\phi 1$ and $\mathrm{Mx}$ ) were highly expressed from $12 \mathrm{hpi}$ to $48 \mathrm{hpi}$ in both groups, with a tendency of increase first and then decline later. Particularly, the $15{ }^{\circ} \mathrm{C}$ group showed quicker and stronger expression of interferon-related genes in contrast. Thus, we can predict that the early activation of interferon-related genes in gibel carp infected with CyHV-2 at $15{ }^{\circ} \mathrm{C}$ may be correlated with the disease resistance, which is well supported by the previous report, pointing out that the quicker induction of interferon-related genes was essential to overcome viral pathogenicity (Poynter \& DeWitte-Orr, 2016).

Inflammation could prevent spread of infection as a protected mechanism against the invading pathogens (Nuriev \& Johansson, 2019). In most cases, virus infection could trigger an intracellular inflammatory response that includes increasing expression of proinflammatory cytokines, including TNF- $\alpha$ and IL-1 $\beta$. The expression of these cytokines plays essential roles involved in activating the IFN and other immune-related pathways. In this study, when gibel carp infected with CyHV-2 at $15{ }^{\circ} \mathrm{C}$, the two proinflammatory cytokines 
(TNF- $\alpha$ and IL-1 $\beta$ ) in the spleens were up-regulated from at $12 \mathrm{hpi}$ and $24 \mathrm{hpi}$ and subsequently maintained at a low level by the end of the trial. In the $25^{\circ} \mathrm{C}$ group, the expression profiles of two genes exhibited a similar trend. However, the genes were immediately upregulated at $12 \mathrm{hpi}$ with slight extension compared to those in the $15{ }^{\circ} \mathrm{C}$ group. Similarly, the upregulation of the proinflammatory cytokines at the early phase of virus infection was also described in hirame rhabdovirus-infected flounder (Zhang et al., 2017). However, it was noted that the duration of upregulation of the proinflammatory cytokines was longer after CyHV-2 infection at $15{ }^{\circ} \mathrm{C}$. This suggested that virus failed to depress the inflammatory response in the host at the adaptation period at the less-susceptible temperature.

Previous study reported that CyHV-2 could induce apoptosis in host cells during their infection cycles (lu \& Lu, 2018). Apoptosis, the programmed cell death process of damaged cells, plays a vital role in the normal development and steady state of host cells. FAS is a transmembrane receptor located on the cell membrane, which can trigger the activation of death receptor signal pathway, regulate the secretion of Caspase 8 and lead to apoptosis (Song et al., 2021). In our study, FAS and Caspase- 8 was very low at $12 \mathrm{hpi}$ and $24 \mathrm{hpi}$ in both the experimental groups, implying that the apoptosis induced by CyHV-2 infection was inhibited at an early stage. This is consistent with the previous study which reported that VHSV suppresses apoptotic genes at early stage of viral infection (Kole et al., 2019). It is worth noting that the two genes showed a relatively higher expression level in the $15^{\circ} \mathrm{C}$ group than that in the $25^{\circ} \mathrm{C}$ group during 48-96 hpi. Similarly, the higher expression of apoptosis-related genes at the late infection stage was also observed in the VHSV-infected fish at the lesssusceptible temperature(Kole et al., 2019).

The activity of antioxidative enzyme in serum is often used to evaluate the immune state of a fish (Meng et al., 2017). Increasing evidence have shown that virus infection can induce overproduction of reactive oxygen species (ROS), which leads to oxidative stress within host cells (Kim et al., 2012). SOD and CAT enzymes, the main antioxidant enzymes in fish, are significant defenses against the ROS produced in cells. Here, we examined the activities of SOD and CAT in the serum. As shown in Figure 3, a significant reduction in SOD and CAT activities in CyHV-2 infected gibel carp was observed at both 15 ${ }^{\circ} \mathrm{C}$ and $25^{\circ} \mathrm{C}$. It agrees with the previous report that virus infection can stimulate ROS production and inhibit antioxidant enzyme levels (Wang et al., 2012). Besides, it is noteworthy that the levels of the antioxidant enzymes in the $15{ }^{\circ} \mathrm{C}$ group were relatively higher than those in the $25{ }^{\circ} \mathrm{C}$ group at the late stage of virus
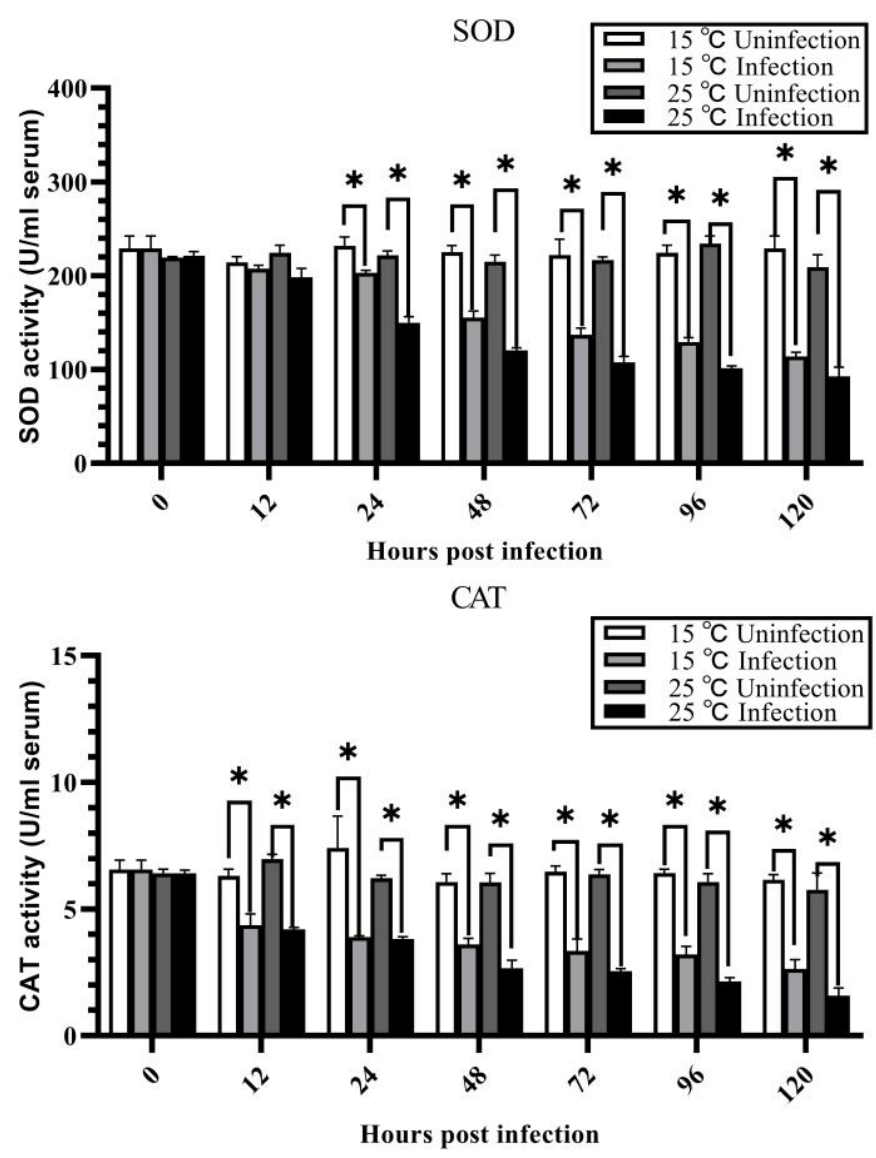

Figure 3. Activities of SOD and CAT in the serum of gibel carp maintained at $15^{\circ} \mathrm{C}$ and $25^{\circ} \mathrm{C}$. 
infection, suggesting that severity of depletion in enzymatic antioxidant defenses may be alleviated when CyHV-2 infected at less-susceptible temperature.

\section{Conclusion}

In conclusion, we investigated the differences of viral replication, antiviral gene expression and antioxidant enzyme activity in gibel carp infected with CyHV-2 under $15^{\circ} \mathrm{C}$ and $25^{\circ} \mathrm{C}$. Compared with the $25^{\circ} \mathrm{C}$ group, fish in the $15{ }^{\circ} \mathrm{C}$ group showed a stronger and quicker induction of interferon-related genes and proinflammatory genes at the early infection stage, and more powerful apoptotic response and antioxidant defense at the late infection stage. Taken together, water temperature affected the immune response against CyHV-2 infection, which may ultimately lead to host survival in the less-susceptible temperatures. The study would help us to gain an insight on the relationship between temperature and CyHV-2 infection, providing a certain value in developing the control measures for gibel carp hematopoietic necrosis.

\section{Ethical Statement}

Authors declare no ethical statement.

\section{Funding Information}

Work supported by the Natural Science Foundation of Jiangsu Province of China (BK20181053), the Jiangsu Agricultural Science and Technology Innovation Fund (CX(18)3028), and the Talent Introduction Program at Yancheng Institute of Technology (Grant no. xjr2019044).

\section{Author Contribution}

Jialin Zhang: Conceptualization, Writing -review and editing; Shaodong Meng: Methodology, Visualization and Writing -original draft; Heng Ge: Writing -review and editing; Shanling Sun: Writing review and editing; Xinran Yu: Methodology, Visualization; Guo Qiao: Writing - review and editing; Qiang Li: Funding Acquisition, Project Administration, Resources.

\section{Conflict of Interest}

The author(s) declare that they have no known competing financial or non-financial, professional, or personal conflicts that could have appeared to influence the work reported in this paper.

\section{References}

Avunje, S., Kim, S., Oh, J., Choi, I., \& Jung, J. (2012). Temperature-dependent viral replication and antiviral apoptotic response in viral haemorrhagic septicaemia virus (VHSV)-infected olive flounder (Paralichthys olivaceus). Fish \& Shellfish Immunology, 32(6), 11621170.https://doi.org/https://doi.org/10.1016/j.fsi.2012. 03.025

Chai, W., Qi, L., Zhang, Y., Hong, M., Jin, L., Li, L., \& Yuan, J. (2020). Evaluation of Cyprinid Herpesvirus 2 latency and reactivation in Carassius gibel. Microorganisms, 8, 445. https://doi.org/10.3390/microorganisms8030445

Chung, J. S., Pitula, J. S., Schott, E., Alvarez, J. V., Maurer, L., \& Lycett, K. A. (2015). Elevated water temperature increases the levels of reo-like virus and selected innate immunity genes in hemocytes and hepatopancreas of adult female blue crab, Callinectes sapidus. Fish \& Shellfish Immunology, 47(1), 511-520.

https://doi.org/https://doi.org/10.1016/j.fsi.2015.09.02 7

Mou, C. Y., Wang, Y., Zhang, Q. Y., Gao, F. X., Li, Z., Tong, J. F., Zhou, L., \& Gui, J. F. (2018). Differential interferon system gene expression profiles in susceptible and resistant gynogenetic clones of gibel carp challenged with herpesvirus CaHV. Dev Comp Immunol, 86, 52-64. https://doi.org/10.1016/j.dci.2018.04.024

Fichi, G., Cardeti, G., Cocumelli, C., Vendramin, N., Toffan, A., Eleni, C., Siemoni, N., Fischetti, R., \& Susini, F. (2013). Detection of Cyprinid herpesvirus 2 in association with an Aeromonas sobria infection of Carassius carassius (L.), in Italy. Journal of Fish Diseases, 36. https://doi.org/10.1111/jfd.12048

Grayfer, L., \& Belosevic, M. (2009). Molecular characterization, expression and functional analysis of goldfish (Carassius aurutus L.) interferon gamma. Dev Comp Immunol, 33(2), 235-246. https://doi.org/10.1016/j.dci.2008.09.001

Ito, T., Kurita, J., Ozaki, A., Sano, M., Fukuda, H., \& Ototake, M. (2013). Growth of cyprinid herpesvirus 2 (CyHV-2) in cell culture and experimental infection of goldfish Carassius auratus. Dis Aquat Organ, 105(3), 193-202. https://doi.org/10.3354/dao02627

Ito, T., \& Maeno, Y. (2014). Effects of experimentally induced infections of goldfish Carassius auratus with cyprinid herpesvirus 2 (CyHV-2) at various water temperatures. Diseases of Aquatic Organisms, 110, 193-200. https://doi.org/10.3354/dao02759

Jung, S., \& Miyazaki, T. (1995). Herpesviral haematopoietic necrosis of goldfish, Carassius auratus (L.). Journal of Fish Diseases, 18, 211-220. https://doi.org/10.1111/j.13652761.1995.tb00296.x

Kalayci, G., Ozkan, B., Pekmez, K., Kaplan, M., Mefut, A., \& Cagirgan, A. (2018). First detection of Cyprinid herpesvirus-2 (CyHV-2) followed by screening and monitoring studies in Goldfish (Carassius Auratus) in Turkey. Bulletin of the European Association of Fish Pathologists, 38, 94-103.

Kayansamruaj, P., Pirarat, N., Hirono, I., \& Rodkhum, C. (2014). Increasing of temperature induces pathogenicity of Streptococcus agalactiae and the up-regulation of inflammatory related genes in infected Nile tilapia (Oreochromis niloticus). Vet Microbiol, 172(1-2), 265271. https://doi.org/10.1016/j.vetmic.2014.04.013

Kim, D., Naruse, S., Kadomura, K., Nakashima, T., Jiang, Z., Yamasaki, Y., Yamaguchi, K., \& Oda, T. (2012). Transitional reactive oxygen species (ROS) production in fertilized egg embryos of devil stinger (Inimicus japonicus), a marine fish species. Bioscience, biotechnology, and biochemistry, 76, 1561-1564. https://doi.org/10.1271/bbb.120184 
Kim, S., Kim, R., Kim, D., Kim, O., Park, A., Kitamura, I., Kim, Y. Kim, H., Han, J., Jung, J., \& Oh, J. (2009). An outbreak of VHSV (viral hemorrhagic septicemia virus) infection in farmed olive flounder Paralichthys olivaceus in Korea. Aquaculture, 296(1), 165-168.

https://doi.org/https://doi.org/10.1016/j.aquaculture.2 009.07.019

Kole, S., Avunje, S., \& Jung, J. (2019). Differential expression profile of innate immune genes in the liver of olive flounder (Paralichthys olivaceus) against viral haemorrhagic septicaemia virus (VHSV) at host susceptible and less-susceptible temperatures. Aquaculture, 503, 51-58.

https://doi.org/https://doi.org/10.1016/j.aquaculture.2 018.12.085

Li, Z., Liang, H., Wang, Z.-W., Zou, G.-W., \& Gui, J.-F. (2016). A novel allotetraploid gibel carp strain with maternal body type and growth superiority. Aquaculture, 458, 55-63. https://doi.org/10.1016/j.aquaculture.2016.02.030

Liu, B., Zhou, Y., Li, K., Hu, X., Wang, C., Cao, G., Xue, R., \& Gong, C. (2018). The complete genome of Cyprinid herpesvirus 2 , a new strain isolated from Allogynogenetic crucian carp. Virus Research, 256, 6-10.

https://doi.org/https://doi.org/10.1016/j.virusres.2018. 07.016

Liu, M., Wu, T., Li, S., Wei, P., Yan, Y., Gu, W., Wang, W., \& Meng, Q. (2018). Combined transcriptomic/proteomic analysis of crucian carp Carassius auratus gibelio in cyprinid herpesvirus 2 infection. Fish Shellfish Immunol, 82, 386-399. https://doi.org/10.1016/j.fsi.2018.07.057

Lu, J., \& Lu, L. (2018). A novel cell line established from caudal fin tissue of Carassius auratus gibelio is susceptible to cyprinid herpesvirus 2 infection with the induction of apoptosis. Virus Research, 258. https://doi.org/10.1016/j.virusres.2018.09.010

Meng, Y., Ma, R., Ma, J., Han, D., Xu, W., Zhang, W., \& Mai, K. (2017). Dietary nucleotides improve the growth performance, antioxidative capacity and intestinal morphology of turbot (Scophthalmus maximus). Aquaculture Nutrition, 23(3), 585-593. https://doi.org/https://doi.org/10.1111/anu.12425

Mou, C.-Y., Wang, Y., Zhang, Q.-Y., Gao, F.-X., Li, Z., Tong, J.-F., Zhou, L., \& Gui, J.-F. (2018). Differential interferon system gene expression profiles in susceptible and resistant gynogenetic clones of gibel carp challenged with herpesvirus CaHV. Developmental \& Comparative Immunology, 86, 52-64. https://doi.org/https://doi.org/10.1016/j.dci.2018.04.024

Nuriev, R., \& Johansson, C. (2019). Chemokine regulation of inflammation during respiratory syncytial virus infection. F1000Research, 8, 1837. https://doi.org/10.12688/f1000research.20061.1

Ouyang, P., Zhou, Y., Geng, Y., Lai, W., Huang, X., Chen, D., Guo, H., Fang, J., Chen, Z., Tang, L., Huang, C., Liu, W., \& Yin, L. (2020). First report of Cyprinid herpesvirus 2 outbreak in cultured gibel carp, Carassius auratus gibelio at low temperature. Journal of the World Aquaculture Society, 51. https://doi.org/10.1111/jwas.12681

Piamsomboon, P., Inchaisri, C., \& Wongtavatchai, J. (2016). Climate factors influence the occurrence of white spot disease (WSD) in cultured penaeid shrimp in Chanthaburi province, Thailand. Aquaculture Environment Interactions, 8. https://doi.org/10.3354/aei00176

Poynter, S., \& DeWitte-Orr, S. (2016). Fish interferonstimulated genes: The antiviral effectors. Developmental \& Comparative Immunology, 65. https://doi.org/10.1016/j.dci.2016.07.011

Qiao, G., Zhang, M., Li, Y., Xu, C., Xu, D.-H., Zhao, Z., Zhang, J., \& Li, Q. (2018). Biofloc technology (BFT): An alternative aquaculture system for prevention of Cyprinid herpesvirus 2 infection in gibel carp (Carassius auratus gibelio). Fish \& Shellfish Immunology, 83, 140-147. https://doi.org/https://doi.org/10.1016/j.fsi.2018.09.015

Ren, W., Pan, X., Dai, C., Shu, T., Li, L., \& Yuan, J. (2021). Investigation of Cyprinid herpesvirus 2 and bacterial coinfection in Carassius gibel. Aquaculture, 537, 736521. https://doi.org/10.1016/j.aquaculture.2021.736521

Song, Z., Tian, X., \& Shi, Q. (2021). Fas, Caspase-8, and Caspase9 pathway-mediated bile acid-induced fetal cardiomyocyte apoptosis in intrahepatic cholestasis pregnant rat models. Journal of Obstetrics and Gynaecology Research, 47. https://doi.org/10.1111/jog.14765

Wang, D.-L., Zuo, D., Wang, L.-M., Sun, T., Wang, Q., \& Zhao, Y.-L. (2012). Effects of white spot syndrome virus infection on immuno-enzyme activities and ultrastructure in gills of Cherax quadricarinatus. Fish \& Shellfish Immunology, 32(5), 645-650. https://doi.org/https://doi.org/10.1016/j.fsi.2012.01.005

Wang, H., Xu, L., \& Lu, L. (2015). Detection of cyprinid herpesvirus 2 in peripheral blood cells of silver crucian carp, Carassius auratus gibelio (Bloch), suggests its potential in viral diagnosis. Journal of Fish Diseases, 39. https://doi.org/10.1111/jfd.12340

Xu, J., Zeng, L., Zhang, H., Zhou, Y., Ma, J., \& Fan, Y. (2013). Cyprinid herpesvirus 2 infection emerged in cultured gibel carp, Carassius auratus gibelio in China. Veterinary Microbiology, 166(1), 138-144.

https://doi.org/https://doi.org/10.1016/j.vetmic.2013.0 5.025

Xu, L., Podok, P., Xie, J., \& Lu, L. (2014). Comparative analysis of differential gene expression in kidney tissues of moribund and surviving crucian carp (Carassius auratus gibelio) in response to cyprinid herpesvirus 2 infection. Arch Virol, 159(8), 1961-1974. https://doi.org/10.1007/s00705-014-2011-9

Zhang, J., Cui, Z., Hu, G., Jiang, X., Wang, J., Qiao, G., \& Li, Q. (2020). Transcriptome analysis provides insights into the antiviral response in the spleen of gibel carp (Carassius auratus gibelio) after poly I: C treatment. Fish \& Shellfish Immunology, 102, 13-19. https://doi.org/https://doi.org/10.1016/j.fsi.2020.03.065

Zhang, J., Tang, X., Sheng, X., Xing, J., \& Zhan, W. (2017). The influence of temperature on viral replication and antiviral-related genes response in hirame rhabdovirusinfected flounder (Paralichthys olivaceus). Fish \& Shellfish Immunology, 68, 260-265. https://doi.org/https://doi.org/10.1016/j.fsi.2017.07.029

Zhu, M., Liu, B., Cao, G., Hu, X., Wei, Y., Yi, J., Zhou, Y., Pan, G., Wang, J., Xue, R., \& Gong, C. (2015). Identification and rapid diagnosis of the pathogen responsible for haemorrhagic disease of the gill of Allogynogenetic crucian carp. Journal of virological methods, 219, 67-74. https://doi.org/https://doi.org/10.1016/j.jviromet.2015 .03 .019 